\title{
Gambaran Stres pada Mahasiswa Tingkat III yang akan Uji Kompetensi di Fakultas IImu Kesehatan UNW Mataram
}

\author{
Erniawati Pujiningsih $^{1^{*}}$ dan Sofian Hadi ${ }^{1}$ \\ ${ }^{1}$ Jurusan Ilmu Keperawatan, Universitas Nahdlatul Wathan Mataram \\ *Email : ernia.fikunwmataram@gmail.com
}

\begin{abstract}
Abstrak : Stres merupakan tekanan yang terjadi akibat ketidak sesuaian anatara situasi yang diinginkan dengan harapan, dimana terdapat kesenjangan antara tuntutan lingkungan dengan kemampuan individu yang memenuhinya yang dinilai potensial membahayakan, mengancam, mengganggu, dan tidak terkendali. Penelitian ini dilakukan untuk mengetahui gambaran stres pada mahasiswa tingkat III Fakultas Ilmu Kesehatan UNW Mataram yang akan mengikuti uji kompetensi.

Penelitian ini merupakan penelitian diskriptif dimana didapatkan jumlah sampel 23 responden yang menggunakan tehnik random sampling untuk mengetahui gambaran stres. Hasil penelitian didapatkan bahwa sebagian besar responden berjenis kelamin perempuan sebanyak 22 mahasiswa (95\%). Sedangkan berdasarkan usia, sebagian besar responden berusia 21 tahun sebanyak 20 responden $(87 \%)$. gambarani stress yang dialami mahasiswa tingkat III yang akan uji kompetensi menunjukan bahwa sebanyak 7 responden (30\%) mengalami stress Ringan dan terdapat 15 responden (65\%) mengalami stress Sedang sedangkan 1 responden (4\%) mengalami stress Berat.

Penelitian ini dilakukan secara online ditengah kondisi pandemi virus corona, sehingga dikhawatirkan terdapat pengaruh psikologis pandemic virus corona terhadap timbulnya stres sehingga mempengaruhi pengisian kuisoner penelitian.
\end{abstract}

Kata Kunci : Stres, Mahasiswa, Uji Kompetensi

\section{Pendahuluan}

Stres merupakan tekanan yang terjadi akibat ketidak sesuaian anatara situasi yang diinginkan dengan harapan, dimana terdapat kesenjangan antara tuntutan lingkungan dengan kemampuan individu yang memenuhinya yang dinilai potensial membahayakan, mengancam, mengganggu, dan tidak terkendali. Stres akademik didapatkan dari banyak faktor, Kohn dan Frazer (Simbolon, 2015) menemukan lima penyebab paling signifikan yang biasa dialami oleh mahasiswa, antara lain nilai akhir, tugas yang berlebihan, paper, ujian yang akan datang dan persiapan untuk ujian tersebut. Sedangkan menurut Misra dan Castillo (Simbolon, 2015) stres akademik diakibatkan karena frustasi, konflik, tekanan-tekanan, perubahan-perubahan, dan beban yang dilimpahkan pada diri sendiri. Pada dasarnya, mahasiswa pasti akan merasakan hal-hal yang sebelumnya dibahas, oleh karena itu stres yang dialami mahasiswa dapat dikatakan normal. Apabila stres yang dirasakan mahasiswa merupakan stres yang berat, dimana mahasiswa dapat turun pencapaian akademik, terganggu kemampuan untuk berpartisipasi dan berkontribusi dalam kehidupan kampus, bahkan mulai menggunakan obat-obat terlarang dan menimbulkan perilaku yang merusak, itu merupakan hal yang tidak wajar maupun normal.

Pelaksanaan Uji kompetensi Ners di Indonesia telah dilaksanakan sebanyak limabelas kali. Hasil UKNI dari tahun ke tahun mengalami tingkat kelulusan yang fluktuatif, data nasional Direktorat Penjaminan Mutu 3 tahun terakhir yaitu pada tahun 2017, peserta yang mengikuti UKNI yang dinyatakan kompeten/lulus berjumlah 20.754 $(51,15 \%)$ dan yang dinyatakan tidak kompeten/lulus berjumlah 19.822 (48.85\%), pada tahun 2018 peserta yang dinyatakan kompeten/lulus berjumlah $26.208(54,89 \%)$ dan yang dinyatakan tidak kompeten/lulus berjumlah 21.535. (45.11\%), pada tahun 2019 peserta yang dinyatakan kompeten/lulus berjumlah $29.240 \quad(55,16 \%)$ dan yang dinyatakan tidak kompeten/lulus berjumlah 21.535 (44.84\%) (Ristek Dikti, 2020).

Ujian Kompetensi Ners Indonesia (UKNI) Periode pertama sampai periode ketiga tingkat kelulusan peserta secara nasional mencapai $100 \%$ kompeten. Namun sejak Sejak periode keempat tahun 2015 terjadi penurunan jumlah kelulusan peserta yang signifikan yaitu 67,51\% kompeten. Penurunan tersebut juga terjadi berturut-turut pada periode berikutnya yaitu periode kelima 56,23\%, keenam $53,77 \%$, ketujuh $52,25 \%$, hingga periode kedelapan $49,72 \%$, dan secara bertahap terjadi kenaikan persentase namun bersifat fluktuatif secara periodik dapat diuraikan yaitu periode kesembilan 51,02\%, kesepuluh 52,59\%, kesebelas $48,49 \%$, keduabelas $60,81 \%$, ketigabelas $48,04 \%$, keempatbelas $49,81 \%$, dan kelimabelas $64,24 \%$ (Ristek Dikti, 2020). Data tersebut menunjukkan bahwa tingkat lulusan uji kompetensi ners secara nasional yaitu periode terakhir masih sangat rendah 
dengan persetase rata-rata yaitu 53,17\% (Ristek Dikti, 2020) .

Dari data yang didapatkan dari Tata Usaha Fakultas Ilmu Kesehatan Universitas Nahdatul Wathan Mataram terdapat 2 mahasiswa keperawatan yang tidak lulus uji kompetensi dari 15 mahasiswa keperawatan yang mengikuti uji kompetensi pada tahun 2020. Data tersebut diatas merupakan salah satu penyebab stres pada mahasiswa, dimana uji kompetensi merupakan salah satu syarat untuk melamar pekerjaan.

\section{Metode Penelitian}

Jenis penelitian yang digunakan adalah penelitian deskritif dimana pengumpulan data didapatkan dari sampel dengan karakteristik responden yang akan mengikuti uji kompetensi. tehnik pengumpulan data dilakukan dengan mengumpulkan data dari kuesioner yang di sebar melalui google form. Tekhnik sampling yang digunakan adalah simple random sampling yaitu pengambilan anggota sampel dari populasi dilakukan secara acak tanpa memperhatikan strata yang ada dalam populasi itu.

\section{Hasil dan Pembahasan}

\section{Hasil}

Distribusi responden berdasarkan karakteristik dari 23 responden dapat dilihat pada tabel di bawah ini :

Tabel 1. Distribusi responden berdasarkan jenis kelamin

\begin{tabular}{|c|c|c|}
\hline Jenis kelamin & Jumlah & Presentase \% \\
\hline Prempuan & 22 & $96 \%$ \\
\hline Laki-laki & 1 & $4 \%$ \\
\hline Jumlah & $\mathbf{2 3}$ & $\mathbf{1 0 0 \%}$ \\
\hline
\end{tabular}

Berdasarkan tabel diatas menunjukkan bahwa responden yang berjenis kelamin perempuan lebih dominan dibandingkan responden yang berjenis kelamin laki-laki yakni sebanyak 22 Responden (96\%) dan yang paling rendah adalah responden laki-laki sebanyak 1 (4\%).

Distribusi responden berdasarkan 3 prodi yaitu Perawat, Bidan, Farmasi yang dapat dilihat pada tabel di bawah ini :

Tabel 2. Distribusi responden berdasarkan prodi:

\begin{tabular}{|c|c|c|}
\hline Prodi & Jumlah & Presentase \% \\
\hline Perawat & 1 & $4 \%$ \\
\hline Bidan & 3 & $13 \%$ \\
\hline Farmasi & 19 & $83 \%$ \\
\hline Jumlah & $\mathbf{2 3}$ & $\mathbf{1 0 0 \%}$ \\
\hline
\end{tabular}

Berdasarkan tabel diatas menunjukkan bahwa Prodi Farmasi lebih mendominasi yakni sebanyak 19 responden (83\%), diikuti oleh Prodi Bidan yakni sebanyak 3 responden (13\%), dan selanjutnya adalah Prodi Perawat yakni sebanyak 1 responden $(4 \%)$.

Distribusi responden berdasarkan usia dari 23 responden

Tabel 3. Distribusi Responden berdasarkan usia

\begin{tabular}{|c|c|c|}
\hline Usia & Jumlah & Presentase \% \\
\hline 21 & 20 & $87 \%$ \\
\hline 22 & 2 & $9 \%$ \\
\hline 24 & 1 & $4 \%$ \\
\hline Jumlah & $\mathbf{2 3}$ & $\mathbf{1 0 0 \%}$ \\
\hline
\end{tabular}

Berdasarkan table diatas, menunjukan bahwa ratarata dari responden berusia 21 tahun yakni sebanyak 20 responden (87\%).

Gambaran stress pada mahasiswa tingkat III FIK UNW Mataram yang akan mengikuti ujian kompetensi tahun 2021

Tabel 4. Gambaran stress pada mahasiswa tingkat III FIK UNW Mataram yang akan mengikuti ujian kompetensi tahun 2021

\begin{tabular}{|c|c|c|}
\hline $\begin{array}{c}\text { Gambaran } \\
\text { Stress }\end{array}$ & $\mathbf{N}$ & Presentase \% \\
\hline Ringan & 7 & $30,434 \%$ \\
\hline Sedang & 15 & $65,217 \%$ \\
\hline Berat & 1 & $4,347 \%$ \\
\hline Total & $\mathbf{2 3}$ & $\mathbf{1 0 0 \%}$ \\
\hline
\end{tabular}

Berdasarkan tabel diatas tentang distribus gambarani stress yang dialami mahasiswa tingkat III yang akan uji kompetensi menunjukan bahwa sebanyak 7 responden $(30,434 \%)$ mengalami stress Ringan dan terdapat 15 responden $(65,217 \%)$ mengalami stress Sedang sedangkan 1 responden $(4,347 \%)$ mengalami stress Berat.

\section{Pembahasan}

\section{Identifikasi Karakteristik Responden}

Berdasarkan jenis kelamin responden paling banyak yaitu berjenis kelamin perempuan dengan presentase $96 \%$ sebanyak 22 responden sedangkan yang berjenis kelamin laki-laki 1 responden dengan presentase $4 \%$.

Berdasarkan program studi responden paling banyak yaitu program studi Farmasi sebanayk 19 responden dengan presentasi 83\%, selanjutnya program studi Kebidanan sebanyak 3 responden dengan presentasi $13 \%$ sedangkan dengan program studi Keperawatan dengan presentase $4 \%$ sebanyak 1 responden. 
Berdasarkan usia dari 23 responden menunjukan bahwa rata-rata responden berusia 21 tahun yakni sebanyak 20 responden (87\%).

\section{Mengidentifikasi Gambaran stress mahasiswa}

Dari hasil penelitian yang telah didapatkan melalui Google Form pada gambaran stress pada mahasiswa tingkat III FIK UNW Mataram menunjukan bahwa 7 responden $(30,434 \%)$ mengalami stress Ringan dan terdapat 15 responden $(65,217 \%)$ mengalami stress Sedang sedangkan 1 responden $(4,347 \%)$ mengalami stress Berat.

Henricus, 2016 stres meningkatkan risiko dari mahasiswa untuk mengalami berbagai gangguan penyakit fisik yang meliputi Dkekebalan tubuh menurun, sakit kepala, sakit jantung, gangguan tekanan darah, hilangnya energi, alergi dan stroke. Adapun gejala stres yang banyak ditunjukkan oleh mahasiswa antara lain gangguan tidur seperti kesulitan tidur, serta adanya gangguan daya ingat.

Gejala stres bersifat fisik yang dirasakan responden juga dikategorikan Kurang apabila pernyataan responden yang mengatakan tidak sesuai dengan dirinya atau tidak pernah dirasakan dalam dirinya. Seperti tidak menghabiskan banyak energi, tidak teramat gemetar, dan detak jantung stabil. Gejala stres fisik ringan ini juga terjadi akibat adanya langkah yang baik dalam menanggulangi gejala stres bersifat fisik yang dirasakan, misalnya dengan melakukan hal-hal yang membuat keadaan tubuh stabil yakni lari pagi, menggerak-gerakkan badan (senam) hal ini diungkapkan dalam penelitian yang dilakukan oleh Ismiati (2015) mengenai coping stres mahasiswa. Di sisi lain terdapat 15 responden mengalami gejala stres bersifat cukup. Gejala stres fisik berat dikategorikan apabila mayoritas jawaban responden terkait beberapa hal yang dirasakan.

Hal tersebut dilatarbelakangi oleh beberapa pernyataan responden yang mengatakan sangat sering menghabiskan banyak energi untuk merasa cemas memikirkan banyaknya tugas yang haus diselsaikan.

\section{Kesimpulan}

Dari hasil penelitian terhadap Gambaran Stres Pada Tingkat III Yang Akan Uji Kompetensi Di Fakultas Ilmu Kesehatan Mataram Tahun 2021 dan sudah menyelsaikan tugas akhir program dapat diambil kesimpulan :

1. Berdasarkan karakteristik responden dilihat dari Jenis kelamin 23 responden sebagian besar adalah responden yang berjenis kelamin perempuan yaitu berjumlah 22 responden (95\%). Berdasarkan Prodi, dari 23 responden sebagian besar adalah responden dari prodi Farmasi yakni sebanyak 19 responden (83\%). Sedangkan berdasarkan usia dari 23 responden sebagian besar adalah responden berusia 21 tahun sebanyak 20 responden $(87 \%)$.
2. Berdasarkan distribusi gambarani stress yang dialami mahasiswa tingkat III yang akan uji kompetensi menunjukan bahwa sebanyak 7 responden (30\%) mengalami stress Ringan dan terdapat 15 responden $(65 \%)$ mengalami stress Sedang sedangkan 1 responden $(4 \%)$ mengalami stress Berat.

\section{Daftar Pustaka}

Achroza, Faela Hanika. "Hubungan Antara Komunikasi Interpersonal Dosen Pembimbing Mahasiswa dan Problem Focused Coping dengan Stres dalam Menyusun Skripsi pada Mahasiswa FKIP Bimbingan dan Konseling Universitas Muria Kudus”.Skripsi. Fakultas Psikologi. Universitas Muria Kudus, 2009.

Adawiyah, Rabiatul. "Analisis Tingkat Stres Mahasiswa dalam Menghadapi Penyusunan Skripsi".Skripsi.Fakultas Ekonomi dan Bisnis.Universitas Muhammadiyah Yogyakarta, 2017.

Agung G \& Budiani MS. "Hubungan kecerdasan dan self efficacy dengan tingkat stres mahasiswa yang sedang mengerjakan skripsi”.Skripsi.Universitas Negeri Surabaya, 2013.

Ali, Zaidin. Agama, Kesehatan dan Keperawatan, Jakarta: CV. Trans Info Media. h. 81, 2010.

Cestari, V. R. F., Barbosa, I. V., Florencio, R. S., de Paula Pessoa, V. L. M., \& Moreira, T. M. M. (2017). Stress in nursing students: study on sociodemographic and academic vulnerabilities. Acta paulista de enfermagem, 30(2), 19

Ismiati."Problematika dan Coping Stres Mahasiswa dalam Menyusun Skripsi”. Jurnal Psikologi. Fakultas Dakwah dan Komunikasi.Universitas Ar-Raniry Banda Aceh, 2015.

Julianti, Rina dkk."Hubungan Komunikasi Antara Mahasiswa dan Dosen Pembimbing Skripsi dengan Stres dalam Menyusun Skripsi pada Mahasiswa S1 Keperawatan Stikes Ranah Minang Tahun 2015". Jurnal Keperawatan. Fakultas Ilmu Keperawatan. Stikes Ranah Minang, 2015.

Roan, W., M. Gatotkaca Terserang Stres. Intisari: Mind, Body, and Soul, 202-211. Jakarta: PT. Intisari Mediatama, 2005.

Wisudaningtyas.Kecemasan Dalam Menghadapi Ujian Skripsi Ditinjau Dari Self Efficacy Pada Mahasiswa Fakultas Psikologi Universitas Katolik Soegijapranata Semarang. Lembaran Ilmu Pendidikan Jurnal Unnes. 2012; 31(2)[

Wiyatmo, Mundilarto, Suharyanto \&Widodo.Efektivitas Bimbingan Tugas Akhir Skripsi Mahasiswa Jurusan Pendidikan Fisika MIPA UNY. 
World Health Organization (WHO). (2006). The World Health Report 2006: Working Together For Health. World Health Organization.

World Health Organization (WHO).(2013). Guidelines For The Management Of Conditions That Are Specifically Related To Stress.World Health Organization. 